\title{
PENGARUH UMUR PANEN PUCUK DAN KONSENTRASI POC URIN KELINCI TERHADAP PERTUMBUHAN DAN PRODUKSI PUCUK KENIKIR (Cosmos caudatus)
}

\author{
(The Effect of Shoots Harvest Time and Concentration of Liquid Organic Fertilizer Rabbit Urin on \\ Kenikir (Cosmos caudatus) Growth and Shoot Production) \\ DIAN MARDIANSYAH ${ }^{1}$, SITI NURHIDAYAH ${ }^{1 *}$, ISMAIL SALEH $^{2}$ \\ ${ }^{1}$ Program Studi Agroteknologi Fakultas Pertanian Universitas Perjuangan Tasikmalaya \\ Jalan Peta No 177 Tawang Kota Tasikmalaya, Jawa Barat, Indonesia 46115 \\ ${ }^{2}$ Staf Pengajar Program Studi Agroteknologi Fakultas Pertanian Universitas Swadaya Gunung Jati \\ Jalan Pemuda No 32, Cirebon, Jawa Barat, Indonesia, 45132 \\ *E-mail: nurhidayah.unper@gmail.com
}

\begin{abstract}
Kenikir is an indigenous plant that has the potential to be cultivated, but there are still many people who do not know the potential of kenikir. This research aims to study the effect of shoots harvest on the results of kenikir and to find the best concentration of liquid organic fertilizer rabbit urin for the growth of kenikir. This research was conducted in January - April 2020 in the experimentation field of Perjuangan University of Tasikmalaya at an altitude of $359 \mathrm{~m}$ asl. The design used was a two factor Randomized Complete Block Design (RCBD). The first factor is the age of harvest, consisting of 3 levels ie 7 WAP (Weeks after planting), 8 WAP and 9 WAP. The second factor is urin concentration consisting of 4 levels ie $0 \mathrm{ml} \cdot \mathrm{L}^{-1}, 10 \mathrm{ml} \cdot \mathrm{L}^{-1}, 20 \mathrm{ml} \cdot \mathrm{L}^{-1}$ and $30 \mathrm{ml} . \mathrm{L}^{-1}$. The results showed that $10 \mathrm{ml} . \mathrm{L}^{-1}$ U2 treatment produced higher kenikir plants and thicker diameters. U2P3 treatment gave the best response to plant height variables. All treatment combinations gave the same response to the number of leaves harvested and the weight of fresh shoots.
\end{abstract}

Keywords : antioxidant, harvest shoots, indigenous plant, organic farming

\section{PENDAHULUAN}

Kenikir (Cosmos caudatus) merupakan salah satu tanaman berjenis sayuran indigenous yang memiliki potensi untuk dibudidayakan, tetapi masih banyak masyarakat yang belum mengetahui potensi dari kenikir dan masih sedikit yang mengkonsumsi kenikir sehingga jarang dibudidayakan oleh masyarakat. Penelitian yang dilakukan oleh Saleh et al. (2020) dari 32 responden hanya 11 orang (34.38\%) yang mengetahui dan menkonsumsi kenikir, sementara 21 orang lainnya $(65.62 \%)$ tidak pernah menkonsumsi kenikir. Sebagai tanaman indigenous, daun kenikir memiliki kandungan antosianin yang bermanfaat sebagai antioksidan untuk pangan manusia (Amsya et al. 2013; Munthe 2016; Revianto et al. 2016; Saleh et al. 2020). Daun kenikir juga digunakan sebagai obat tradisional untuk mengobati kanker, diabetes dan juga digunakan sebagai diuretik (Sekar et al. 2014). Berdasarkan penelitian Nurhaeni et al. (2014) aktivitas antioksidan pada ekstrak kenikir paling tinggi dengan nilai IC50 $19.49 \mu \mathrm{g} / \mathrm{ml}$. Umumnya kenikir dibudidayakan untuk diambil pucuk daunnya digunakan sebagai sayuran atau lalapan, dan dijual di pasar tradisional.

Penelitian yang dilakukan Delyani dan

Kartika (2016) menyebutkan bahwa kekurangan air pada awal pertumbuhan dapat mengakibatkan tanaman menginisiasi pembungaan lebih awal. Apabila pucuk daun dipetik maka tunas baru akan tumbuh kembali. Pemanenan yang dilakukan secara teratur akan menunda pembungaan dan akan terus memproduksi tunas baru. Pemanenan pucuk daun kenikir yaitu memotong cabang muda yang telah berukuran sekitar $30 \mathrm{~cm}$. Penelitian yang dilakukan oleh Amsya et al. (2013) perlakuan pemupukan dengan petroganik dan urea pada pemanenan pertama belum memberikan pengaruh yang nyata. Pada saat memasuki pemanenan kedua, bobot segar tanaman kenikir menunjukkan respon nyata. Hal ini disebabkan saat pemanenan tahap kedua, umur tanaman semakin tua sehingga 
diameter batang mengalami perubahan ukuran dan lebih banyak memunculkan tunas lateral atau cabang baru yang lebih segar. Hal tersebut didukung dari Haryanti (2020) bahwa urin kelinci memiliki kandungan unsur hara $\mathrm{N}$ (2.72\%), P (1.1\%), dan K (0.5\%) yang diperlukan untuk pertumbuhan tanaman.

Menurut Chusna (2016) tanaman kenikir memiliki potensi untuk dikembangkan karena pucuk kenikir dapat dipanen secara berulang. Salah satu upaya yang dapat dilakukan bagaimana memberikan input yang dapat mempengaruhi pertumbuhan dan hasil tanaman kenikir. Beberapa penelitian atau percobaan yang telah dilakukan dalam memanfaatkan POC urin kelinci yang dapat memberikan respon yang berbeda - beda diantaranya pemberian campuran $A B$ mix Joro+Paitan+kotoran kelinci cair menghasilkan bobot segar terbaik pada tanaman sawi (Nurrohman 2014), konsentrasi POC kelinci 80 ml. $\mathrm{L}^{-1}$ memberikan pengaruh pada berat konsumsi tangkai daun dan berat konsumsi daun horenso (Simanjuntak \& Heddy 2014), dosis $20 \mathrm{ml}^{-1}$ berpengaruh terhadap karakter vegetatif dan generatif tanaman wortel (Gustia 2016), pada dosis $212-250 \mathrm{ml}$ per polybag memberikan hasil berbeda-beda pada tanaman seledri (Segari et al. 2017). Penelitian ini bertujuan untuk mengetahui korelasi umur panen pucuk dan konsentrasi pupuk organik cair urin kelinci terhadap pertumbuhan dan hasil tanaman kenikir.

\section{BAHAN DAN METODE}

Penelitian ini dilaksanakan pada bulan Januari - April 2020 di Lapangan Percobaan Universitas Perjuangan Tasikmalaya pada ketinggian \pm 359 mdpl.

Bahan yang digunakan dalam percobaan ini adalah benih kenikir (Cosmos caudatus), polybag ukuran $20 \mathrm{~cm} \times 10 \mathrm{~cm}$, dan media tanam tanah yang sudah digemburkan. Alat yang digunakan dalam penelitian ini adalah cangkul, sekop kebun, emerat, baki semai, gelas ukur, timbangan analitik, jangka sorong, kamera, penggaris, dan alat tulis. Pupuk organik cair (POC) yang digunakan adalah urin kelinci yang sudah difermentasikan dengan campuran EM4 dan gula merah selama 1 bulan. POC diaplikasikan sebanyak 2 kali, yaitu pada saat tanaman berumur 1 Minggu Setelah Tanam (MST) dan diaplikasikan kembali setelah pemanenan pertama.

Rancangan percobaan yang digunakan adalah Rancangan Kelompok Lengkap Teracak dengan dua faktor. Faktor pertama adalah umur pemanenan terdiri dari 3 taraf :

$$
\begin{aligned}
& \mathrm{P} 1=\text { pemanenan } 7 \mathrm{MST} \\
& \mathrm{P} 2=\text { pemanenan } 8 \mathrm{MST} \\
& \mathrm{P} 3=\text { pemanenan } 9 \mathrm{MST}
\end{aligned}
$$

Faktor kedua adalah konsentrasi urin

kelinci terdiri dari 4 taraf :

$$
\begin{aligned}
& \mathrm{U} 1=0 \mathrm{ml} \cdot \mathrm{L}^{-1} \\
& \mathrm{U} 2=10 \mathrm{ml} \cdot \mathrm{L}^{-1} \\
& \mathrm{U} 3=20 \mathrm{ml} \cdot \mathrm{L}^{-1} \\
& \mathrm{U} 4=30 \mathrm{ml} \cdot \mathrm{L}^{-1}
\end{aligned}
$$

Kombinasi dua faktor di atas menghasilkan 12 kombinasi perlakuan dan setiap perlakuan diulang sebanyak 3 kali sehingga terdapat 36 unit percobaan. Setiap unit percobaan terdiri atas 4 polybag dan setiap polybag diisi 1 bibit kenikir menggunakan jarak tanam $50 \mathrm{~cm} \times 30 \mathrm{~cm}$ sehingga didapatkan 144 tanaman kenikir.

Variabel yang diamati diantaranya tinggi tanaman, diameter batang $(\mathrm{cm})$, jumlah daun, jumlah cabang per tanaman, bobot segar panen pucuk $\left(\right.$ g.tanaman ${ }^{-1}$ ), jumlah daun yang dipanen, dan total panen pucuk per tanaman (g.tanaman $\left.{ }^{-1}\right)$.

Data yang diperoleh dari hasil pengamatan kemudian dianalisis menggunakan ANOVA, jika perlakuan berpengaruh nyata terhadap peubah yang diamati maka diuji lanjut dengan uji DMRT taraf $a=5 \%$ dengan menggunakan aplikasi STAR 2.0.1.

\section{HASIL DAN PEMBAHASAN}

\section{Kondisi Umum}

Kondisi pertumbuhan tanaman kenikir pada awal penanaman secara keseluruhan tumbuh dengan seragam dan baik. Penyiraman dilakukan sehari dua kali yaitu pagi dan sore hari. Selama penelitian terdapat OPT yang mengganggu pertumbuhan tanaman, sehingga diperlukan penyulaman untuk mengganti tanaman yang mati akibat serangan hama belalang pada saat awal pindah tanam. Saat tanaman dewasa beberapa OPT mulai menyerang tanaman seperti kutu daun (Aphis sp.), ulat (Hyphantria cunea), dan belalang. Gulma yang terdapat di sekitar tanaman didominasi oleh gulma berdaun lebar seperti daun sendok (Plantago major) dan gulma lainnya seperti rumput jari (Digitaria).

Tabel 1. Hasil analisis kandungan POC urin kelinci dan Standar Mutu kandungan NPK

\begin{tabular}{cccc}
\hline No & Parameter & $\begin{array}{c}\text { Konsentrasi } \\
\text { kandungan }\end{array}$ & Standar Mutu \\
\hline 1. & $\mathrm{~N}$ & $0.15 \%$ & $3-6 \%$ \\
2. & $\mathrm{P}_{2} \mathrm{O}_{5}$ & $0.20 \%$ & $3-6 \%$ \\
3. & $\mathrm{~K}_{2} \mathrm{O}$ & $2.28 \%$ & $3-6 \%$ \\
\hline
\end{tabular}


Pupuk organik cair urin kelinci merupakan hasil dari fermentasi dengan penambahan mikroorganisme untuk proses dekomposisi kandungan. Menurut Susilowati dan Sarwitri (2018) urin kelinci termasuk pupuk organik cair yang bersifat slow release yaitu membutuhkan suatu proses dekomposisi untuk diserap akar tanaman. Menurut Syamsiah dan Royani (2014), untuk mempercepat proses dekomposisi tersebut unsur hara NPK memerlukan suatu dukungan dari mikroorganisme yang berasal dari pupuk hayati dan urin kelinci sebagai penyuplai, sehingga terjadi interaksi antar keduanya sehingga dapat mempercepat pertumbuhan dan perkembangan tanaman. Menurut Siregar (2017) EM4 merupakan campuran dari berbagai jenis mikroorganisme yang mempunyai manfaat untuk meningkatkan keragaman mikrobia tanah. Penggunaan EM4 diharapkan dapat mempercepat proses dekomposisi pada urin kelinci. Pada Tabel 1 menunjukkan hasil analisis $\mathrm{POC}$ urin kelinci yang digunakan, kandungan $\mathrm{N}, \mathrm{P}$, dan $\mathrm{K}$ berbeda dengan hasil penelitian lain yang menunjukkan unsur hara $\mathrm{N}$ dan $\mathrm{P}$ lebih tinggi diatas $1 \%$. Hal ini diduga pakan kelinci yang diberikan mengandung kalium yang tinggi.

\section{Rekapitulasi Sidik Ragam pada Karakter Agronomi Tanaman Kenikir}

Tabel 2. Rekapitulasi analisis ragam perlakuan POC

\begin{tabular}{lccr}
\multicolumn{1}{c}{ urin kelinci } & & & \\
\hline Karakter & MST & Uji F & KK (\%) \\
\hline Tinggi tanaman (cm) & 1 & $*$ & 1.84 \\
& 2 & tn & 5.23 \\
& 3 & tn & 4.39 \\
& 4 & tn & 3.96 \\
& 5 & tn & 6.23 \\
Jumlah daun & 6 & $*$ & 4.14 \\
& 7 & $*$ & 4.01 \\
& 1 & tn & 7.63 \\
& 2 & tn & 9.65 \\
& 3 & tn & 6.70 \\
& 4 & tn & 6.36 \\
& 5 & tn & 9.40 \\
& 6 & tn & 6.67 \\
& 7 & tn & 5.50 \\
& 5 & tn & 16.78 \\
& 6 & tn & 14.4 \\
& 7 & $*$ & 4.45 \\
\hline
\end{tabular}

Keterangan: tn $=$ tidak nyata, ${ }^{*}=$ berpengaruh nyata berdasarkan analisis ragam pada taraf $a=5 \%$

Berdasarkan uji $\mathrm{F}$ pada Tabel 2, perlakuan POC urin kelinci memberikan pengaruh nyata terhadap karakter tinggi tanaman (1 MST, $6 \mathrm{MST}$, dan $7 \mathrm{MST}$ ), dan karakter diameter batang 7 MST. Pemberian POC urin kelinci berkorelasi positif terhadap karakter tinggi tanaman (1 MST, 6 MST, dan 7 MST), dan karakter diameter batang 7 MST menunjukkan efektivitas urin kelinci sesuai dengan waktu pengaplikasian.

Tabel 3. Rekapitulasi analisis ragam perlakuan POC urin kelinci, umur panen pucuk dan interaksinya

\begin{tabular}{|c|c|c|c|c|}
\hline \multirow{2}{*}{ Karakter } & \multicolumn{3}{|c|}{ Uji F } & \multirow{2}{*}{$\begin{array}{l}\mathrm{KK} \\
(\%)\end{array}$} \\
\hline & Panen & Urin & Interaksi & \\
\hline Tinggi Tanaman & * & * & * & 18.20 \\
\hline Jumlah Daun & tn & tn & tn & 7.79 \\
\hline Diameter Batang & tn & tn & tn & 11.23 \\
\hline Jumlah Cabang & tn & th & $\operatorname{tn}$ & 9.00 \\
\hline
\end{tabular}

Berdasarkan Tabel 3, perlakuan POC urin kelinci, umur panen maupun interaksinya memberikan pengaruh nyata terhadap karakter tinggi tanaman. Namun tidak berpengaruh nyata terhadap karakter jumlah daun, diameter batang, dan jumlah cabang tanaman kenikir.

Nilai KK (koefisien keragaman) berbeda tergantung pada percobaan yang dilakukan, tanaman yang diteliti, dan sifat atau karakter yang diuji. Semakin rendah nilai koefisien keragaman maka tingkat kepercayaan akan semakin tinggi. Namun tidak ada nilai KK yang bisa dijadikan ketentuan karena dapat dipengaruhi oleh faktor di lapangan (Gomez and Gomez 2010, Harsojuwono et al. 2011).

\section{Tinggi Tanaman}

Tabel 4. Rata-rata tinggi tanaman kenikir pada perlakuan konsentrasi urin yang berbeda umur 1, 6 dan 7 MST

\begin{tabular}{llll}
\hline Konsentrasi & $1 \mathrm{MST}$ & $6 \mathrm{MST}$ & $7 \mathrm{MST}$
\end{tabular}

POC

Urin kelinci

\begin{tabular}{cccc}
\hline U1 $0 \mathrm{ml} . \mathrm{L}^{-1}$ & $5.82^{\mathrm{a}}$ & $13.59^{\mathrm{a}}$ & $19.02^{\mathrm{a}}$ \\
U2 $10 \mathrm{ml} . \mathrm{L}^{-1}$ & $5.54^{\mathrm{bc}}$ & $14.17^{\mathrm{a}}$ & $20.29^{\mathrm{a}}$ \\
U3 $20 \mathrm{ml} . \mathrm{L}^{-1}$ & $5.64^{\mathrm{ab}}$ & $12.27^{\mathrm{b}}$ & $17.18^{\mathrm{b}}$ \\
U4 $30 \mathrm{ml} . \mathrm{L}^{-1}$ & $5.42^{\mathrm{c}}$ & $13.30^{\mathrm{ab}}$ & $18.88^{\mathrm{a}}$ \\
\hline Keterangan: Angka yang diikuti huruf yang sama \\
pada kolom yang sama tidak berbeda \\
berdasarkan uji lanjut DMRT taraf a $=$ \\
5\%
\end{tabular}

Rata-rata tinggi tanaman kenikir sebelum panen dapat dilihat pada Tabel 4 . Rata-rata tinggi tanaman kenikir cenderung mengalami peningkatan setiap minggunya. Pada umur 1 MST tinggi tanaman terbaik pada perlakuan kontrol yaitu $\mathrm{U} 10 \mathrm{ml} \cdot \mathrm{L}^{-1}$ dengan rata-rata tinggi $5.82 \mathrm{~cm}$, sementara perlakuan terendah yaitu perlakuan $\mathrm{U} 430 \mathrm{ml} . \mathrm{L}^{-1}$ dengan rata-rata tinggi tanaman $5.43 \mathrm{~cm}$. Pada umur 6 MST perlakuan U2 $10 \mathrm{ml}^{-\mathrm{L}^{-1}}$ dengan rata-rata tinggi tanaman $14.17 \mathrm{~cm}$ tidak berbeda nyata 
dengan perlakuan U1 $0 \mathrm{ml} \cdot \mathrm{L}^{-1}$ karena rata-rata tinggi tanaman yang hampir sama, sementara perlakuan terendah yaitu U3 $20 \quad \mathrm{ml}^{-\mathrm{L}^{-1}}$ menghasilkan rata-rata tinggi tanaman hanya $12.27 \mathrm{~cm}$. Pada umur 7 MST perlakuan U1 0 $\mathrm{ml} . \mathrm{L}^{-1}$ tidak berbeda nyata dengan perlakuan U2 $10 \mathrm{ml}^{-1}$ dan U4 $30 \mathrm{ml}^{-1} \mathrm{~L}^{-1}$ karena ratarata tinggi tanaman hampir sama sementara itu perlakuan dengan rata-rata tinggi tanaman terendah adalah perlakuan U3 $20 \mathrm{ml}^{-1} \mathrm{~L}^{-1}$.

Tabel 5. Interaksi konsentrasi urin kelinci dan umur panen terhadap rata-rata tinggi tanaman

\begin{tabular}{lccc}
\hline Konsentrasi & P1 & P2 & P3 \\
POC & $7 \mathrm{MST}$ & $8 \mathrm{MST}$ & $9 \mathrm{MST}$ \\
Urin kelinci & & & \\
\hline U1 0 ml. $\mathrm{L}^{-1}$ & $27.39^{\mathrm{a}}$ & $37.06^{\mathrm{a}}$ & $61.00^{\mathrm{b}}$ \\
U2 $10 \mathrm{ml} . \mathrm{L}^{-1}$ & $24.03^{\mathrm{a}}$ & $45.63^{\mathrm{a}}$ & $80.33^{\mathrm{a}}$ \\
U3 $20 \mathrm{ml} . \mathrm{L}^{-1}$ & $21.08^{\mathrm{a}}$ & $46.74^{\mathrm{a}}$ & $50.93^{\mathrm{b}}$ \\
U4 $30 \mathrm{ml} . \mathrm{L}^{-1}$ & $24.13^{\mathrm{a}}$ & $42.83^{\mathrm{a}}$ & $55.54^{\mathrm{b}}$ \\
\hline
\end{tabular}

Keterangan: Angka yang diikuti huruf yang sama pada kolom yang sama tidak berbeda berdasarkan uji lanjut DMRT taraf $\mathrm{a}=$ $5 \%$

Tabel 5 menunjukkan perlakuan umur panen dengan konsentrasi POC urin kelinci pada umur 7 MST dan 8 MST semua perlakuan tidak berbeda nyata. Pada umur 7 MST rata-rata tinggi tanaman berkisar antara $21.08 \mathrm{~cm}$ sampai yang tertinggi $27.39 \mathrm{~cm}$ sementara pada umur 8 MST rata-rata tinggi tanaman berkisar antara $37.06 \mathrm{~cm}$ sampai $46.74 \mathrm{~cm}$. Perlakuan P3U2 memberikan respon tanaman paling tinggi dibandingkan perlakuan lainnya yaitu dengan nilai tinggi tanaman rata-rata $80.33 \mathrm{~cm}$. Hal tersebut didukung oleh penelitian Syamsiah dan Royani (2014), bahwa pemberian urin kelinci dapat memberikan hasil optimal pada karakter tinggi tanaman. Urin kelinci mempunyai kandungan unsur hara $\mathrm{N}$ dan bau gas amoniak $\left(\mathrm{NH}_{3}\right)$ yang bisa digunakan untuk pemupukan. Penelitian yang dilakukan oleh Abuyamin (2016) pemberian dosis urin kelinci $40 \mathrm{ml}^{-1} \mathrm{~L}^{-1}$ mampu menghasilkan tinggi tanaman terbaik pada tanaman caisim. Hasil penelitian yang dilakukan oleh Syamsiah dan Royani (2014) perlakuan pemberian urin kelinci dosis $50 \mathrm{ml} . \mathrm{L}^{-}$ dengan penambahan PGPR mampu memberikan hasil rata-rata tinggi tanaman terbaik pada tanaman cabai.

\section{Jumlah Daun}

Menurut Amiroh dan Rohmad (2017) daun pada tanaman mempunyai peran penting dalam proses penyerapan sinar matahari yang akan diteruskan pada proses fotosintesis tanaman. Daun mempunyai klorofil yang mempunyai peran untuk melakukan proses fotosintesis, selain itu proses fotosintesis diperlukan aerasi yang baik pada media tanam untuk membantu penyerapan air dan unsur hara pada akar tanaman secara optimal dalam mendukung pertambahan luas daun melalui proses metabolisme (Simorangkir et al. 2017).

Tabel 6. Rata-rata jumlah daun kenikir pada perlakuan konsentrasi urin yang berbeda

\begin{tabular}{lcccc}
\hline Konsentrasi & \multicolumn{4}{c}{ Jumlah daun } \\
\cline { 2 - 5 } POC & 4 & 5 & 6 & 7 \\
Urin kelinci & MST & MST & MST & MST \\
\hline U1 0 ml.L'-1 & 8 & 10 & 13 & 17 \\
U2 $10 \mathrm{ml}^{-1} \mathrm{~L}^{-1}$ & 9 & 10 & 14 & 17 \\
U3 $20 \mathrm{ml} . \mathrm{L}^{-1}$ & 8 & 9 & 12 & 16 \\
U4 30 ml.L & 8 & 10 & 13 & 17 \\
\hline
\end{tabular}

Keterangan: Angka yang diikuti huruf yang sama pada kolom yang sama tidak berbeda berdasarkan uji lanjut DMRT taraf $a=$ $5 \%$

Hasil analisis Tabel 6 menunjukkan bahwa pemberian POC urin kelinci tidak memberikan pengaruh nyata terhadap jumlah daun kenikir baik kontrol maupun ke 3 jenis konsentrasi lainnya meskipun terdapat penambahan jumlah daun kenikir pada setiap minggunya. Hal tersebut menunjukkan bahwa pemberian POC urin kelinci $10-30 \mathrm{ml}^{-1} \mathrm{~L}^{-1}$ belum mampu memberikan respon yang optimal terhadap jumlah daun kenikir.

Tabel 7. Interaksi umur panen dan konsentrasi urin kelinci terhadap jumlah daun

\begin{tabular}{|c|c|c|c|}
\hline \multirow[b]{2}{*}{$\begin{array}{l}\text { Konsentrasi POC } \\
\text { Urin kelinci }\end{array}$} & \multicolumn{3}{|c|}{ Jumlah daun } \\
\hline & $\begin{array}{c}\mathrm{P} 1 \\
7 \mathrm{MST}\end{array}$ & $\begin{array}{c}\text { P2 } \\
8 \mathrm{MST}\end{array}$ & $\begin{array}{c}\text { P3 } \\
9 \mathrm{MST}\end{array}$ \\
\hline U1 $0 \mathrm{ml}^{-\mathrm{L}^{-1}}$ & 18 & 32 & 52 \\
\hline U2 $10 \mathrm{ml}^{-\mathrm{L}^{-1}}$ & 16 & 30 & 52 \\
\hline U3 $20 \mathrm{ml} \cdot \mathrm{L}^{-1}$ & 17 & 35 & 56 \\
\hline U4 $30 \mathrm{ml}^{-\mathrm{L}^{-1}}$ & 17 & 33 & 50 \\
\hline \multicolumn{4}{|c|}{$\begin{array}{l}\text { Keterangan: Angka yang diikuti huruf yang sama } \\
\text { pada kolom yang sama tidak berbeda } \\
\text { berdasarkan uji lanjut DMRT taraf a = } \\
5 \%\end{array}$} \\
\hline
\end{tabular}

Rata-rata jumlah daun setelah panen dapat dilihat pada Tabel 7. Jumlah daun setelah perlakuan umur panen dan pemberian POC urin kelinci tahap ke 2 juga tidak memberikan perbedaan yang nyata, baik pada perlakuan umur panen pucuk P1 maupun umur panen pucuk P2 dan P3. Pemberian POC urin kelinci dengan konsentrasi yang ditentukan dirasa kurang memenuhi untuk perkembangan pada tanaman kenikir, sejalan dengan penelitian yang dilakukan Cahyani et al. (2019) bahwa rendahnya dosis yang diaplikasikan belum mampu memberikan pengaruh pada perkembangan tanaman. Menurut Mutryarny et al. (2014) dan Susilowati dan Sarwitri (2018) pupuk organik mempunyai kelemahan yaitu kandungan hara rendah serta bersifat slow 
release yang artinya membutuhkan waktu bagi tanaman untuk diserap.

\section{Diameter Batang}

Tabel 8. Rata-rata diameter batang kenikir pada perlakuan konsentrasi urin yang berbeda

\begin{tabular}{lccc}
\hline Konsentrasi POC & \multicolumn{3}{c}{ Diameter batang $(\mathrm{mm})$} \\
\cline { 2 - 4 } Urin kelinci & $5 \mathrm{MST}$ & $6 \mathrm{MST}$ & $7 \mathrm{MST}$ \\
\hline U1 $0 \mathrm{ml} . \mathrm{L}^{-1}$ & 2.29 & 3.46 & $5.26^{\mathrm{bc}}$ \\
U2 $10 \mathrm{ml} . \mathrm{L}^{-1}$ & 2.78 & 4.12 & $6.31^{\mathrm{a}}$ \\
U3 $20 \mathrm{ml} . \mathrm{L}^{-1}$ & 2.29 & 3.54 & $4.81^{\mathrm{c}}$ \\
U4 $30 \mathrm{ml} . \mathrm{L}^{-1}$ & 2.67 & 3.93 & $5.51^{\mathrm{b}}$
\end{tabular}

Keterangan: Angka yang diikuti huruf yang sama pada kolom yang sama tidak berbeda berdasarkan uji lanjut DMRT taraf $a=$ $5 \%$

Hasil analisis yang tertera pada Tabel 8 menunjukkan bahwa pemberian POC urin kelinci berbeda nyata terhadap diameter batang pada umur 7 MST sebelum panen. Konsentrasi POC urin kelinci terbaik yaitu 10 $\mathrm{ml} . \mathrm{L}^{-1}$ dengan rata-rata diameter batang tanaman mencapai $6.31 \mathrm{~mm}$ dan berbeda nyata dengan seluruh perlakuan lainnya.

Tabel 9. Interaksi umur panen dan konsentrasi urin kelinci terhadap rata-rata diameter batang

\begin{tabular}{lccc} 
& \multicolumn{3}{c}{ Diameter batang $(\mathrm{mm})$} \\
\cline { 2 - 4 } Konsentrasi POC & Urin kelinci & P2 & P3 \\
& $7 \mathrm{MST}$ & $8 \mathrm{MST}$ & $9 \mathrm{MST}$ \\
\hline U1 0 $\mathrm{ml} . \mathrm{L}^{-1}$ & 7.74 & 8.73 & 9.93 \\
U2 $10 \mathrm{ml} . \mathrm{L}^{-1}$ & 8.23 & 9.73 & 11.49 \\
U3 $20 \mathrm{ml} . \mathrm{L}^{-1}$ & 6.79 & 8.91 & 10.20 \\
U4 $30 \mathrm{ml} . \mathrm{L}^{-1}$ & 7.88 & 9.31 & 9.80 \\
\hline Respon & tn & tn & tn \\
\hline
\end{tabular}

Keterangan: $\mathrm{tn}=$ tidak berbeda nyata berdasarkan uji DMRT taraf $a=5 \%$

Rata-rata diameter batang setelah panen disajikan pada Tabel 9. Hasil analisis menunjukkan bahwa seluruh kombinasi perlakuan yang diuji tidak berbeda nyata terhadap karakter diameter batang. Menurut Abuyamin (2016) pupuk organik seperti urin kelinci memiliki kandungan $\mathrm{N}$ yang rendah sehingga parameter menunjukkan hasil yang hampir sama rata. Hal ini tidak sejalan dengan Amsya et al. (2013) bahwa ukuran diameter batang pada tanaman kenikir akan mempengaruhi hasil panen kedua dikarenakan ukuran tanaman berbeda-beda dan semakin besar.

\section{Jumlah Cabang}

Dalam melakukan pemangkasan pada tanaman akan mempengaruhi produksi auksin ke bagian tunas lateral, maka dengan melakukan pemangkasan diharapkan dapat memunculkan tunas atau cabang baru pada tanaman (Saprudin 2013). Pengamatan jumlah cabang dilakukan setelah masa panen karena kemunculan cabang terjadi setelah perlakuan pemanenan. Setelah dilakukan pemanenan dan pengaplikasian POC urin kelinci, tidak memberikan pengaruh nyata terhadap jumlah cabang. Menurut Sihombing dan Heddy (2018) jika tidak ada interaksi terhadap peubah yang diamati, diduga penggunaan pupuk tidak maksimal menyebabkan nutrisi yang ada tidak dapat diserap oleh tanaman. Selain itu POC urin kelinci yang diaplikasikan kurang untuk memenuhi kebutuhan perkembangan jumlah cabang pada tanaman kenikir. Menurut Prastowo et al. (2013) untuk mendapatkan hasil optimal pada tanaman, pemberian pupuk harus mencukupi kebutuhan tanaman. Berdasarkan pada Tabel 10, tidak adanya interaksi umur panen dan aplikasi POC urin kelinci terhadap jumlah cabang. Meskipun pada perlakuan umur panen 9 MST jumlah cabang semakin bertambah.

Tabel 10. Interaksi umur panen dan konsentrasi urin kelinci terhadap rata-rata jumlah cabang

\begin{tabular}{lccc}
\hline Konsentrasi & \multicolumn{3}{c}{ Jumlah cabang } \\
\cline { 2 - 4 } Prin kelinci & 7 MST & 8 2 MST & 9 MST \\
\hline U1 $0 \mathrm{ml}^{-1}$ & 2 & 4 & 6 \\
U2 $10 \mathrm{ml} . \mathrm{L}^{-1}$ & 2 & 4 & 6 \\
U3 $20 \mathrm{ml} . \mathrm{L}^{-1}$ & 2 & 5 & 7 \\
U4 $30 \mathrm{ml} . \mathrm{L}^{-1}$ & 2 & 5 & 6 \\
\hline Respon & tn & tn & tn \\
\hline Keterangan: & Angka yang diikuti huruf yang sama & sama \\
& pada kolom yang sama tidak berbeda \\
& berdasarkan uji lanjut DMRT taraf a $=$ \\
& 5\%
\end{tabular}

\section{Produksi Pucuk}

Tabel 11. Interaksi perlakuan umur panen dan aplikasi urin kelinci terhadap variabel bobot panen pucuk segar per tanaman (g.tanaman ${ }^{-1}$ )

\begin{tabular}{|c|c|c|c|c|c|c|}
\hline \multirow{2}{*}{$\begin{array}{c}\text { Konsentrasi } \\
\text { POC } \\
\text { Urin kelinci }\end{array}$} & \multicolumn{3}{|c|}{ Panen ke 1} & \multicolumn{3}{|c|}{ Panen ke 2} \\
\hline & P1 & P2 & P3 & P1 & P2 & P3 \\
\hline $\mathrm{U} 10 \mathrm{ml} \cdot \mathrm{L}^{-1}$ & 5.25 & 6.84 & 5.53 & 5.78 & 7.01 & 3.93 \\
\hline $\mathrm{U}_{1}^{\mathrm{U} 2} 10 \mathrm{ml} . \mathrm{L}$ & 6.56 & 5.33 & 6.53 & 3.12 & 4.13 & 1.24 \\
\hline $\mathrm{U}_{1}^{\mathrm{U} 32} 20 \mathrm{ml}^{\mathrm{L}}$ & 5.25 & 4.18 & 3.78 & 4.66 & 5.16 & 3.99 \\
\hline$\bigcup_{1} 430 \mathrm{ml} \cdot \mathrm{L}^{-}$ & 7.17 & 5.56 & 4.33 & 2.85 & 4.30 & 4.33 \\
\hline Respon & tn & tn & tn & tn & tn & tn \\
\hline
\end{tabular}

Hasil analisis perlakuan umur panen dan aplikasi POC urin kelinci terhadap variabel bobot panen segar disajikan pada Tabel 11. Seluruh kombinasi perlakuan yang diuji tidak berbeda nyata terhadap bobot panen segar pucuk. Panen pertama pucuk kenikir dilakukan 
saat tanaman berumur $7 \mathrm{MST}$, sementara itu panen kedua dilakukaan 2 minggu setelah panen pertama. Bagian tanaman yang dipanen adalah bagian yang bisa dijual atau bisa dikonsumsi, yaitu bagian pucuk tanaman kenikir diukur sepanjang $15 \mathrm{~cm}$ dari ujung atas pucuk. Perlakuan umur panen dan perlakuan konsentrasi POC urin kelinci tidak berpengaruh terhadap bobot panen segar tanaman kenikir.

Tabel 12. Interaksi perlakuan aplikasi urin kelinci dan panen pucuk terhadap variabel bobot total panen pucuk (g.tanaman ${ }^{-1}$ )

\begin{tabular}{cccc}
\hline Konsentrasi POC Urin & \multicolumn{3}{c}{ Umur Panen } \\
\cline { 2 - 4 } Kelinci & $\mathrm{P} 1$ & $\mathrm{P} 2$ & $\mathrm{P} 3$ \\
\hline U1 0 ml. ${ }^{-1}$ & 11.03 & 13.85 & 9.46 \\
U2 $10 \mathrm{ml} . \mathrm{L}^{-1}$ & 9.68 & 9.46 & 7.78 \\
U3 $20 \mathrm{ml} . \mathrm{L}^{-1}$ & 9.91 & 9.33 & 7.77 \\
U4 $30 \mathrm{ml} . \mathrm{L}^{-1}$ & 10.02 & 9.86 & 8.67 \\
\hline Respon & tn & tn & tn \\
\hline
\end{tabular}

Keterangan: $\mathrm{tn}=$ tidak nyata berdasarkan uji DMRT taraf $a=5 \%$

Pada Tabel 12 menunjukkan bahwa interaksi umur panen dan aplikasi POC urin kelinci tidak berbeda nyata terhadap bobot total panen segar pucuk per tanaman. Namun demikian, secara umum pelakuan tanpa urin kelinci memiliki total produksi lebih banyak jika dibandingkan dengan penggunaan POC urin kelinci. Perlakuan U1P2 memiliki rata-rata produksi lebih tinggi dan perlakuan U3P3 memberikan rata-rata total panen lebih sedikit jika dibandingkan dengan perlakuan lainnya. Pada perlakuan P3 cenderung mengalami penurunan bobot panen dibanding P1 dan P2. Hal ini disebabkan tanaman pada perlakuan P3 telah memasuki fase generatif sehingga pada saat pemanenan tahap kedua tidak terlalu banyak pucuk yang dipanen.

Tabel 13. Interaksi perlakuan aplikasi urin kelinci dan umur panen terhadap variabel jumlah daun dipanen per tanaman

\begin{tabular}{ccccccc}
\hline $\begin{array}{c}\text { Konsentrasi } \\
\text { POC Urin } \\
\text { Kelinci }\end{array}$ & \multicolumn{2}{c}{ Panen Pertama } & \multicolumn{3}{c}{$\begin{array}{c}\text { Panen } \\
\text { Kedua }\end{array}$} \\
\cline { 2 - 7 } & P1 & P2 & P3 & P1 & P2 & P3 \\
\hline U1 0 ml. $\mathrm{L}^{-1}$ & 4.1 & 4.2 & 4.7 & 7.4 & 11.2 & 8.6 \\
U2 $10 \mathrm{ml}^{-1}$ & 4.2 & 5.0 & 4.4 & 4.7 & 6.8 & 4.9 \\
U3 $20 \mathrm{ml}^{-1} \mathrm{~L}^{-1}$ & 4.3 & 4.8 & 3.5 & 6.2 & 7.8 & 11.2 \\
U4 30 ml. $\mathrm{L}^{-1}$ & 4.7 & 4.0 & 3.7 & 4.3 & 7.6 & 11.7 \\
\hline Respon & tn & tn & tn & tn & tn & tn \\
\hline
\end{tabular}

Keterangan: $\mathrm{tn}=$ tidak nyata berdasarkan uji DMRT taraf $a=5 \%$

Tabel 14. Interaksi perlakuan aplikasi urin kelinci dan panen pucuk terhadap variabel total daun dipanen

\begin{tabular}{lccc}
\hline Konsentrasi POC Urin & \multicolumn{3}{c}{ Umur Panen } \\
\cline { 2 - 4 } Kelinci & P1 & P2 & P3 \\
\hline U1 0 ml. -1 $^{-1}$ & 11.50 & 15.44 & 13.33 \\
U2 $10 \mathrm{ml} . \mathrm{L}^{-1}$ & 8.89 & 11.83 & 9.33 \\
U3 $20 \mathrm{ml} . \mathrm{L}^{-1}$ & 10.50 & 12.56 & 14.72
\end{tabular}

\begin{tabular}{cccc} 
U4 30 ml. $\mathrm{L}^{-1}$ & 9.00 & 11.61 & 15.33 \\
\hline Respon & tn & tn & tn \\
\hline Keterangan: tn = tidak nyata berdasarkan uji & DMRT
\end{tabular} taraf $a=5 \%$

Berdasarkan Tabel 13 dan Tabel 14 menunjukkan bahwa perlakuan umur panen dan aplikasi POC urin kelinci juga tidak memberikan perbedaan nyata terhadap jumlah daun dipanen dan total daun dipanen. Jumlah daun kenikir pada pemanenan tahap kedua hampir semua perlakuan mengalami penambahan jumlah daun yang dipanen, namun salah satu perlakuan yang mengalami penurunan dibanding jumlah daun dipanen pertama yaitu perlakuan P1U4 dikarenakan bobot panen yang kedua hanya $2.85 \mathrm{~g}$, sementara bobot panen pada pemanenan pertama seberat $7.17 \mathrm{~g}$.

Banyaknya daun yang dipanen tidak berbanding lurus dengan bobot panen dikarenakan tidak semua tanaman tumbuh tunas baru. Menurut penelitian yang dilakukan Jatsiyah et al. (2016) saat pemanenan pertama hasil panen tidak sebanyak panen kedua atau periode panen selanjutnya, dikarenakan pada pemanenan pertama jumlah pucuk yang layak untuk dipanen masih sedikit sehingga dapat mempengaruhi hasil panen per bedeng. Pemanenan periode selanjutnya hasil panen akan meningkat dikarenakan saat melakukan pemanenan pertama pemangkasan pucuk dapat merangsang tunas baru untuk dilakukan pemanenan sehingga mempengaruhi bobot panen.

\section{KESIMPULAN DAN SARAN}

\section{Kesimpulan}

1. Perlakuan $P O C$ urin kelinci berpengaruh nyata terhadap variabel tinggi tanaman ( 1 , 6 dan 7 MST) dan diameter batang 7 MST.

2. Perlakuan tunggal U2 $\left(10 \quad \mathrm{ml} . \mathrm{L}^{-1}\right)$ memberikan respon terbaik terhadap tinggi tanaman dan diameter batang kenikir umur 7 MST.

3. Adanya interaksi pemberian urin kelinci dan umur panen pucuk terhadap karakter tinggi tanaman. Perlakuan U2P3 memberikan tinggi terbaik daripada perlakuan lainnya.

\section{Saran}

Diharapkan adanya penelitian lanjutan mengenai umur panen pucuk dengan pengaplikasian POC urin kelinci dengan konsentrasi POC urin kelinci yang lebih tinggi, sehingga didapatkan konsentrasi yang optimal untuk pertumbuhan dan produksi pucuk kenikir. 
Abuyamin. 2016. Pengaruh Pemberian Urin Kelinci dan Kompos terhadap Pertumbuhan dan Hasil Tanaman Caisim (Brassica juncea L.). J Plumula, 5 (1): 69-79.

Amiroh, A., dan M. Rohmad. 2017. Kajian Varietas dan Dosis Urin Kelinci terhadap Pertumbuhan dan Produksi Tanaman Melon (Cucumis Melo L.). J Folium, 1 (1): 37-47.

Amsya, U.N., B. Sutikno, dan S.H Pratiwi. 2013. Pengaruh Pemupukan Organik dan Nitrogen pada Pertumbuhan dan Hasil Tanaman Kenikir (Cosmos caudatus Kunth.). J Agroteknologi Merdeka Pasuruan, 1 (1): 29-34.

Cahyani, N.A., S. Hasibuan, dan R. Mawarni. 2019. Pengaruh Urin Kelinci dan Media Tanam Berbeda terhadap Pertumbuhan dan Produksi Tanaman Selada (Lactuca sativa) Secara Hidroponik dengan Sistem Wick. J Agricultural Research, 15 (1): 20-28.

Chusna, N. 2016. Pengaruh jenis dan dosis pupuk kandang terhadap produksi pemanenan berulang pucuk layak jual kenikir (Cosmos caudatus). Skripsi. Institut Pertanian Bogor. Bogor.

Delyani, R., dan J.G. Kartika. 2016. Pengaruh Pupuk Nitrogen dan Pupuk Cair Hayati terhadap Perumbuhan dan Produksi Sayuran Daun Indigenous Tahunan. Bul. Agrohorti, 4 (3): 336-342.

Gomez, K.A, and A.A. Gomez. 2010. Statistical procedures for agricultural research. John Wiley \& Sons, Inc.

Gustia, H. 2016. Respon Tanaman Wortel Terhadap Pemberian Urin Kelinci. Jurnal Agrosains dan Teknologi, 1 (1): 45-55.

Harsojuwono, B.A., I.W. Arnata, G.A.K.D. Puspawati. 2011. Rancangan percobaan: teori dan apilikasi SPSS dan Excel. Malang (ID): Lintas Kata Publishing.

Haryanti, B.W. 2020. Cara Pembuatan Pupuk Dari Urin Dan Kotoran Kelinci. http://cybex.pertanian.go.id/artikel/93327 /cara-pembuatan-pupuk-dari-urin-dankotoran-kelinci/. Diakses pada tanggal 23 September 2020.

Jatsiyah, V., A.D. Susila, dan M. Syukur. 2016. Kemiripan Dan Evaluasi Produksi Aksesi Kenikir (Cosmos caudatus Kunth.) dari Jawa Barat. J Agronomi Indonesia, 44 (1): 55-61.

Munthe J.R. 2016. Respon kualitas pascapanen kenikir (Cosmos caudatus) terhadap suhu penyimpanan. Skripsi. Departemen Teknik Mesin dan
Biosistem. Institut Pertanian Bogor. Bogor.

Mutryarny, E., Endriani, dan S.U. Lestari. 2014. Pemanfaatan Urin Kelinci untuk Meningkatkan Pertumbuhan dan Produksi Tanaman Sawi (Brassica juncea L) Varietas Tosakan. J IImiah Pertanian, 11 (2): 23-34.

Nurhaeni, F., Trilestari, S. Wahyuono, dan A. Rohman. 2014. Aktivitas Antioksidan Ekstrak Etanolik Berbagai Jenis Sayuran serta Penentuan Kandungan Fenolik dan Flavonoid Totalnya. J Media Farmasi, 11 (2): 167-178.

Nurrohman, M., A Suryanto, dan K Puji. Penggunaan Fermentasi Ekstrak Paitan (Tithonia diversifolia L.) dan Kotoran Kelinci Cair sebagai Sumber Hara pada Budidaya Sawi (Brassica juncea L.) Secara Hidroponik Rakit Apung. Jurnal Produksi Tanaman, 2 (8): $649-657$.

Prastowo B, E. Patola, dan Sarwono. 2013. Pengaruh Cara Penanaman dan Dosis Pupuk Urea terhadap Pertumbuhan dan Hasil Tanaman Selada Daun (Lactuca sativa L.). J Inovasi Pertanian, 12 (2): 41-52.

Revianto, A. Rahayu, Y Mulyaningsih. 2017. Pertumbuhan Dan Produksi Tanaman Kenikir (Cosmos caudatus Kunth.) pada Berbagai Tingkat Naungan. Jurnal Agronida, 3 (2): 76-83.

Saleh, I., U. Trisnaningsih, D. Dwirayani, R.M. Syahadat, dan I.S. Atmaja. 2020. Analisis Preferensi Konsumen terhadap Dua Spesies Kenikir; Cosmos caudatus dan Cosmos Sulphureus. J Mahatani, 3 (1): 195-204.

Saprudin. 2013. Pengaruh Umur Tanaman Pada Saat Pemangkasan terhadap Pertumbuhan dan Hasil Ketimun (Cucumis Sativus L.). Juristek, 1 (2): 51 62.

Segari, A., H. Rianto, Y.E. Susilowati. 2017. Pengaruh Macam Media Dan Dosis Urin Kelinci Terhadap Hasil Tanaman Seledri (Apium graveolens L.). VIGOR: Jurnal Ilmu Pertanian Tropika dan Subtropika, $2(1): 1-4$.

Sekar, M., M.Z.B. Abdullah, A.Y.H.B.N. Azlan, S N B. Nasir, Z.B. Zakaria, M.S.B. Abdullah. 2014. Ten Commonly Available Medicinal Plants in Malaysia Used For The Treatment of Diabetes - A Review. Asian J Pharm Clin Res, 7 (1): 1-5.

Sihombing, M.R., dan S. Heddy. 2018. Pengaruh Pemberian Biourin Kelinci Terhadap Pertumbuhan dan Hasil Beberapa Varietas Selada (Lactuca 
sativa L.). J Produksi Tanaman, 6 (7): 1317-1326.

Simanjuntak, P.G.B.P., dan Y.B.S. Heddy. 2014. Respon Tanaman Horenso Terhadap Media Serbuk Sabut Kelapa (Cocopeat) dan Pupuk Kotoran Cair Kelinci. Jurnal Produksi Tanaman, 2 (8): $649-657$.

Simorangkir, C.A., A. Supriyanto, W.E. Murdiono, E. Nihayati. 2017. Pemberian Pupuk Urin Kelinci (Leporidae) dan $\mathrm{KNO}_{3}$ pada Pertumbuhan dan Hasil Tanaman Stroberi (Fragraria sp.). J Produksi Tanaman, 5 (5): 782-790.

Susilowati, Y.E., dan R. Sarwitri. 2018. Meningkatkan Hasil Tanaman Stroberi dengan Urin Kelinci. J Ilmu Pertanian Tropika dan Subtropika, 3 (1): 25-29.

Syamsiah, M., dan Royani. 2014. Respon Pertumbuhan dan Produksi Tanaman Cabai Merah (Capsicum Annum L.) terhadap Pemberian PGPR (Plant Growth Promoting Rhizobakteri) dari Akar Bambu dan Urin Kelinci. J Agroscience, 4 (2): 109-114. 